\title{
Response of Yield, Yield Components and Oil Quality of some Safflower Genotypes to Harvesting Date
}

\author{
Makkiyah Kadhum Alag', Saddam Hakeem Cheyed ${ }^{1}$, Nazy Awishalem Sarkees ${ }^{2}$ \\ ${ }^{1}$ Field Crops Department, College of Agriculture, University of Baghdad, Baghdad, Iraq \\ ${ }^{2}$ Field Crops Department, College of Agriculture, University of Salahaddin, Erbil, Iraq
}

Email address:

alhakeem@gmail.com (S. H. Cheyed), abotaha_h_2006@yahoo.com (S. H. Cheyed)

\section{To cite this article:}

Makkiyah Kadhum Alag, Saddam Hakeem Cheyed, Nazy Awishalem Sarkees. Response of Yield, Yield Components and Oil Quality of some Safflower Genotypes to Harvesting Date. International Journal of Applied Agricultural Sciences. Vol. 1, No. 2, 2015 , pp. $42-48$. doi: $10.11648 /$ j.ijaas.20150102.15

\begin{abstract}
This study was conducted at experimental field, College of Agriculture, Baghdad University, Abu-Ghraib-Iraq, during winter seasons 2010-2011 and 2011-2012. Randomized Complete Block Design with three replicates arranged in a spiltplot was used. Five genotypes (G2018, Gila, Al-mais, Aurduny and Rabee 500) represents main plots, whereas four harvesting dates at [ physiological maturity (PM), 10, 20 and 30 days after (PM) ] were assigned as sub-plots. In both seasons at physiological maturity stage, the plants attained the highest plant height, number of primary branches per plant, number of heads per plant, 100-seed weight, seed yield, oil content and oil yield. Also, Rabee 500 genotype's plants were characterized by recording the highest number of primary branches per plant, number of heads per plant, 100-seed weight, seed yield and oil content. Aurduny genotype when was harvested at first date obtained the highest seed yield ( 3.5 and $3.6 \mathrm{t} \mathrm{ha-}^{1}$ ) for both seasons, oil content (36.2\%) in 2011-2012 season and the highest oil yield (1.3 t ha- $\left.{ }^{1}\right)$ in 2010-2011 season. In contrast, G2018 genotype obtained the highest oil content (35.4\%) when harvested at the first date in 2010-2011 and oil yield (2.4 tha-1) in 2011-2012 when harvested after 20 days from PM. Plants of first season produced the highest seed yield $\left(2.4 \mathrm{t} \mathrm{ha}^{1}\right)$, while the same plants in the second season were recognized by recording the highest oil content (31.4\%). There was a high significant positive correlation between seed yield with plant height, number of primary branches per plant, number of heads per plant and 100-seed weight. Also, a positive and highly significant correlation between oil yield and seed yield and oil content for both seasons was found.
\end{abstract}

Keywords: Harvesting Date, Oil Content, Oil and Seed Yield, Safflower

\section{Introduction}

Among the oil seed crops, safflower (Carthamus tinctorius L.) from Asteraceae family, is one of the most valuable crops with multipurpose usage which is grown for oil, medicinal and industrial uses, safflower oil is one of the highest quality vegetable oils, containing oleic and linoleic acids (Khan et al., 2009). However the safflower plant can be utilized as grazed forage or stored as hay or silage.

Seed quality of safflower is affected by many factors like genotypes, environment and agronomic practices. Among the agronomic factors affecting the crop growth and yield is the stage of seed development at harvest which influences both safflower yield and seed quality. Harvesting too early may result in low yield and poor seed quality, whereas harvesting too late may result in shattering such as rapeseed. Seed shattering is usually has been not a problem, although safflower should be harvested as soon as it matures to minimize the danger of seed damage from excessive moisture. Excessive rain and high humidity after physiological maturity of the seed may cause sprouting in the head (Mundel et al., 2004). Then the choice of appropriate harvesting date is one of the key points in crop management to obtain high quality and quantity yield, so suggesting of most appropriate harvesting date to farmers increase their yield. The harvest area of safflower throughout the world was about (782641) hectares, produced (647374) tones of average yield (827.2 $\mathrm{kg} \mathrm{ha}^{-1}$ ) according to FAO statistics in 2014. Several studies in safflower, showed that a significant difference between the means of the harvesting in number of heads per plant, 100seed weight and seed yield delay in harvesting were decreased the seed and oil yield, head per plant and 100-seed weight, Mosavi Mogaddam et al. (2013) found that significant interactions between cultivars and harvesting dates on seed yield, oil percentage and harvest index. Isfahan cultivar had the highest yield when harvested at 136 days after sowing. 
However, there is little information available regarding the optimum time for harvesting safflower; thus, the present study was conducted in order to determine the optimum harvest crop genotypes in the region by its high seed yield, oil content and oil yield of these genotypes.

\section{Materials and Methods}

This study was conducted at experimental field, College of agriculture, Baghdad University-Abu Ghraib (west of Baghdad, Latitude $33^{\circ} 22 \mathrm{~N}^{\prime}$ and Longitude $44^{\circ} 24^{\prime} \mathrm{E}, 38$ meter above sea level)-Iraq during two winter growth seasons 2010-2011 and 2011-2012 to study the effect of harvesting date on yield, yield components and oil quality of five safflower genotypes.

A split-plot based on randomized complete block design with three replications was used. Five genotypes (G2018, Gila, Al-mais, Aurduny and Rabee 5000) represented the main plots, whereas four harvesting dates (at physiological maturity PM, After 10, 20 and 30 days from physiological maturity) were assigned as sub-plots. The date of physiological maturity was May 29 in the first season and May 25 in the second season. Safflower's physiological maturity is about 35-40 days after flowering and ready to be harvested when most of leaves have turned brown and only tint of green remains on the bracts of the latest flowering heads. Plants are dry not brittle and seeds should rub freely from the heads (Mundel et al., 2004).

The represented soil samples were taken from various locations of the field at depth $(30-60 \mathrm{~cm})$ after tillage, these samples were air dried, then sieved by using $2 \mathrm{~mm}$ sieve, then packed for analysis, as shown in table (1).

Table 1. Some chemical and physical properties of field soil.

\begin{tabular}{|c|c|c|c|c|c|c|c|c|c|c|}
\hline & \multicolumn{3}{|c|}{ PSD ( $\mathrm{g} \mathrm{kg}^{-1}$ soil) } & \multirow{2}{*}{ Soil texture } & \multirow{2}{*}{$\mathbf{p H}$} & \multirow{2}{*}{$\operatorname{Ec}\left(d s . m^{-1}\right)$} & \multirow{2}{*}{$\begin{array}{l}\text { O.M (g } \\
\left.\mathrm{kg}^{-1}\right)\end{array}$} & \multirow{2}{*}{$\begin{array}{l}\text { Available } \\
\text { N (mg kg } \text { soil })^{-1}\end{array}$} & \multirow{2}{*}{$\begin{array}{l}\text { Available } \\
\left.\text { P (mg kg }{ }^{-1} \text { soil }\right)\end{array}$} & \multirow{2}{*}{$\begin{array}{l}\text { Available } \\
\left.\text { K (mg kg }{ }^{-1} \text { soil }\right)\end{array}$} \\
\hline & Clay & Silt & Sand & & & & & & & \\
\hline $2010-2011$ & 315 & 550 & 135 & Silt clay loam & 7.4 & 2.3 & 3.2 & 35 & 14.28 & 270 \\
\hline 2011-1012 & 310 & 560 & 130 & Silt clay loam & 7.5 & 2.4 & 3.2 & 38 & 20.35 & 281 \\
\hline
\end{tabular}

Central Laboratory of Soil and Water Resources Dept./College of Agriculture/Baghdad University

The field was cross plowed twice, softened and leveled and then the land was divided mechanically to furrows, each replicate consisted of 20 experimental units $(3 \times 3) \mathrm{m}^{2}$ containing four furrow, each $3 \mathrm{~m}$ long. Sowing was performed manually on 12 November, 2010 and 21 November 2011, two seeds were sowed in hole of 2-3 cm depth, plants were $30 \mathrm{~cm}$ apart and furrows were $75 \mathrm{~cm}$ apart to achieve nearly plant density of 44444.44 plants per hectare. Nitrogen fertilizer was added at a rate of $120 \mathrm{~N} \mathrm{~kg} \mathrm{ha}^{-1}$ in the form of urea $(46 \% \mathrm{~N})$ at three intervals; the first at sowing date with $\mathrm{P}_{2} \mathrm{O}_{5}$ was drilled near the seeds and covered at a rate of $80 \mathrm{P}_{2} \mathrm{O}_{5} \mathrm{~kg} \mathrm{ha}^{-1}$ in the form of triple superphosphate $\left(46 \% \mathrm{P}_{2} \mathrm{O}_{5}\right)$ (Martin et al., 2006). The second interval of nitrogen fertilizer was added at main stem elongation and the last was added at $50 \%$ of flowering (Dahnk et al., 1992 and Deedar, 1994). The Meteorological data of both seasons in Abu-Ghraib location was given in (Table 2).

Table 2. Meteorological data of both seasons in Abu-Ghraib location.

\begin{tabular}{|c|c|c|c|c|c|c|c|c|c|}
\hline \multirow{3}{*}{ Months } & & \multicolumn{4}{|c|}{ Average Temp. $\left({ }^{\circ} \mathrm{C}\right)$} & \multicolumn{4}{|c|}{ Relative humidity (\%) } \\
\hline & & \multicolumn{2}{|c|}{$2010-2011$} & \multicolumn{2}{|c|}{ 2011-2012 } & \multicolumn{2}{|c|}{$2010-2011$} & \multicolumn{2}{|c|}{ 2011-2012 } \\
\hline & & Min. & Max. & Min. & Max. & Min. & Max. & Min. & Max. \\
\hline \multirow{4}{*}{ March } & $1-10$ & 11.1 & 23.9 & 8.7 & 21.5 & 32.1 & 82.5 & 21.2 & 69.6 \\
\hline & $11-20$ & 14.8 & 28.7 & 7.1 & 22.9 & 18.5 & 57.9 & 17.1 & 68.3 \\
\hline & $21-31$ & 10.5 & 24.2 & 10.5 & 25.9 & 29.7 & 76.9 & 18.9 & 76.5 \\
\hline & $1-10$ & 14.7 & 29.7 & 13.9 & 29.5 & 17.9 & 68.6 & 17.8 & 56.9 \\
\hline April & $11-20$ & 14.9 & 27.4 & 14.0 & 30.1 & 19.6 & 73.5 & 12.6 & 53.9 \\
\hline \multirow{3}{*}{ May } & $1-10$ & 18.2 & 33.9 & 17.3 & 32.7 & 16.7 & 69.7 & 19.7 & 68.4 \\
\hline & $11-20$ & 24.9 & 29.5 & 20.4 & 31.2 & 12.7 & 45.3 & 15.4 & 53.3 \\
\hline & $21-31$ & 21.9 & 39.7 & 21.6 & 39.3 & 10.0 & 45.7 & 11.6 & 46.8 \\
\hline \multirow{3}{*}{ June } & $1-10$ & 24.5 & 43.1 & 24.3 & 41.8 & 9.1 & 41.9 & 9.9 & 50.0 \\
\hline & $11-20$ & 26.5 & 43.7 & 23.2 & 39.4 & 9.8 & 41.7 & 11.4 & 46.5 \\
\hline & $21-30$ & 23.5 & 38.5 & 24.4 & 42.8 & 12.6 & 42.9 & 9.0 & 38.5 \\
\hline
\end{tabular}

Three plants were randomly selected from each experimental unit to measure plant height (which was measured as the length of the stem from soil surface to the top of the plant), number of primary branches per plant, number of heads per plant, number of seeds per head and 100 -seed weight. Total seed yield was obtained by harvesting plants' samples from the mid furrow to calculate seed yield per hectare. Harvesting index was calculated by using the following: formula:

$$
\mathrm{HI}=\frac{\text { See yield }}{\text { Biological yield }} \times 100
$$

Oil was extracted from safflower seeds using Soxhlet, and oil percentage was estimated according to Association of Official Analytical Chemists (A.O.A.C., 1980). Oil yield was calculated as follows:

$$
\text { Oil yield }\left(\mathrm{kg} \mathrm{ha}^{-1}\right)=\mathrm{Oil} \% \times \text { Seed yield }\left(\mathrm{kg} \mathrm{ha}^{-1}\right)
$$

The data analysis was conducted statistically for all studied 
traits according to variance of analysis using the Statistical Analysis System (SAS Institute 2005) program. Duncan's multi-range test at level of $5 \%$ was used to determine means (Steel and Torrie, 19600. Simple correlation coefficient was calculated between the seed yield and other traits and among the traits themselves for both seasons.

\section{Results and Discussion}

In both seasons; genotypes, harvesting dates and their interaction had significant effect on all traits studied (Tables 3, 4, 5 and 6). In the first season (2010-2011), plants of Gila, Almais, G2018 and Aurduny genotypes produced the same highest plant height $(149.1,149.1,148.7$ and $147.1 \mathrm{~cm})$ respectively, compared to Rabee 500 genotypes plants, while in the second season (2011-2012) plants of Gila produced the highest plant height $(116.9 \mathrm{~cm})$ compared to Rabee 500 genotype (Table 3). This result is in agreement with Soleyman et al. (2011) who reported that the highest plant height was related to Zarghan cultivar compared to the rest of cultivars. It is noticed that plants harvested at physiological maturity stage (first harvest date) in two seasons attained the highest length (154.2 and $117.3 \mathrm{~cm}$ ) respectively, while the lowest was for plants harvested after 30 days of physiological maturity (Table 4). The tallest plants were in the first season $(146.9 \mathrm{~cm})$ compared to the second season $(107.5 \mathrm{~cm})$. Gila genotype's plants in both seasons recorded the highest plant height when the plants harvested at physiological maturity stage compared to Raboo 500 genotype when harvested in last harvest date (Tables 5 and 6).

Rabee 500 genotype in both seasons produced the highest number of primary branches (18.3 and 20.3) for both seasons respectively; this result is probably related to the genetic nature of branches formation under certain conditions. Also it is noticed from table (4) that plants harvested at physiological maturity stage in both seasons produced the highest number of primary branches per plant compared to the rest of dates. Also Aurduny genotype in the first season and Al-mais genotype in the second season produced the highest number of primary branches when harvested at physiological maturity stage (Tables 5and 6).

Rabee 500 genotype's plants planted in both seasons produced the highest number of heads (62.5 and 61.3) respectively. First harvesting date plants in each season recorded the highest number of heads per plant compared to the other dates, especially the late harvest date(after 30 dates of $\mathrm{PM})$; this decline is attributed to decrease the number of primary branches (Table 2) which has a negatives effect on number of heads per plant. From tables (5) (6), Rabee 500 genotype in the first season and Al-mais genotype in the second season recorded the highest number of heads per plant when harvested at the harvest date (physiological maturity).

Data of table (3) and (4) revealed that Gila genotype in 2010-2011 season and G2018 in the 2011-2012 season recorded the highest number of seeds per head (32.4 and 28.1) for both genotypes respectively. From the same tables revealed that harvesting after 30 days of PM in the first season on and after 20 days of PM recorded the highest number of seeds per head (32.1 and 26.1) respectively which increases at (81.4 and $35.9 \%$ ) respectively in comparison to the first date (PM). The highest number of seeds per head was in the first season (26.1) and the lowest was in the second season (21.4). Also G2018 genotypes plants in both seasons produced the highest number of seeds per head when harvested after 30 and 20 days of physiological maturity for both seasons respectively (Tables 5 and 6).

The highest 100-seed weight was recorded for Rabee 500 (5.04 and $4.18 \mathrm{~g}$ ) in both seasons respectively, while the lowest was recorded to the rest of genotypes (Table 3). Also the first harvest date's plants gave the highest 100-seed weight (4.91 and $4.22 \mathrm{~g}$ ) in both seasons respectively in comparison with harvesting date 30 days of PM. The first season's plants gave the highest weight of 100-seed (4.66 g), while the second gave the lowest (3.61 g) (Table 3). Rabee 500 genotype plants produced the highest 100-seed weight (5.51 and $4.95 \mathrm{~g}$ ) in both seasons respectively when harvested at physiological maturity stage (Tables 5 and 6).

The results of tables (3) and (4) indicate that Rabee 500 genotype's plants gave the highest seed yield in both seasons, while Al-mais genotype's plants for the same seasons caused a decline in yields by (25.3 and $34.0 \%$ ) respectively, the increase in yield of Rabee 500 genotype was due to increasing one or more of its components as the number of heads per plant $(62.5$ and 61.3) which was a result of increasing of the number of primary branches per plant (18.3 and 20.3) and 100-seed weight (5.04 and $4.18 \mathrm{~g}$ ) in both seasons respectively (Table 3 ) was one of reasons for the yield rising. Also it was found that plants harvested at physiological maturity stage gave the highest seed yield (3003.0 and $2700.1 \mathrm{~kg} \mathrm{ha}^{-1}$ ) for both seasons respectively, compared with plants harvested after 30 days of PM (1814.1 and $1128.2 \mathrm{~kg} \mathrm{ha}^{-1}$ ) respectively. This result is in agreement with Mosovi Moguddam et al. (2013) who found that delay in harvesting decreased seed yield, oil yield, heads per plant and 100-seed weight. It is noticed that there is a high significant positive correlation relationship between seed yield with plant height, number of primary branches/plant, number of heads per plant for both seasons and with number of seeds per head and 100-seed weight for both seasons (Appendix 2). However, data of table (3) shows that plants belonged to first season produced highest rate for this trait $\left(2414.3 \mathrm{~kg} \mathrm{ha}^{-1}\right)$ compared with seed yields of the second season, this may be due to increase of number of seeds per head with 100 -seed weight in addition to climatic conditions which differences between both seasons (Table 2). The seed yield had the highest values reached (3.5 and $3.6 \mathrm{t} \mathrm{ha}^{-1}$ ) when Aurduny genotype's plants harvested at first date (physiological maturity) comparing to the rest of interactions (Tables 5 and 6).

The results show that Al-mais genotype and plants harvested after 20 days of PM in the first season as well as G2018 genotype and plants harvested after 30 days of PM in the second season gave the highest harvest index (33.9 and 27.2\%) and $(25.3$ and $25.2 \%)$ for both seasons respectively (Tables 3 and 4). Also, Al-mais genotype when harvested after 20 days of PM in 2010-2011, as well as Gila genotype when harvested 
after 30 days of PM in 2011-2012 season recorded the highest harvest index (Tables 5 and 6).

The highest oil percentage was gained by Rabee 500 in both seasons (32.5 and 33.8) respectively. This result was in agreement with Mohankumar and Chimmad (2005) who pointed out the existence of significant differences among cultivars for oil content. In addition to plants of genotypes produced the highest oil content when harvesting at physiological maturity (33.7 and $34.6 \%)$ in both seasons respectively. The oil content reduced with delay 30 day of PM by $(21.1$ and $19.4 \%)$ comparison to the first harvest date. The increase of oil content may be due to increase in temperature during flowering to maturity and the higher oil accumulation with increase in temperature is similar to other oil seed crops (Qadir et al., 2006). From tables (5) and (6), the highest oil content were (35.4 and 36.2) procure by the G2018 genotype in 2010-2011 season and Aurduny genotype in 2011-2012 season when both harvested at physiological maturity compare with the other interactions. The second season (2011-2012) was superior to $(31.4 \%)$ the first season which recorded $(30.1 \%)$, this was due to the difference in temperature and relative humidity between both seasons (Table 2 ).

From data of tables (3) and (4); the optimum values of oil yield were recorded by Al-mais genotype ( $\left.842.1 \mathrm{~kg} \mathrm{ha}^{-1}\right)$ in the first season and by G2018 genotype (1108.1 $\left.\mathrm{kg} \mathrm{ha}^{-1}\right)$ in the second season, in addition to the optimum oil yield were (1007.7 and $939.1 \mathrm{~kg} \mathrm{ha}^{-1}$ ) acquired by harvesting at physiological maturity stage, while the minimum values were (483.2 and $315.6 \mathrm{~kg} \mathrm{ha}^{-1}$ ) acquired by harvesting after 30 days of PM at both seasons respectively. The reason of increase oil yield in early harvesting date (physiological maturity) is the result of increase seed yield and the oil content in the same stage (Table 4). A positive and highly significant correlation was between oil yield with seed yield and oil content for both seasons $\left(\mathrm{r}=0.941^{* *}\right.$ and $\left.0.727^{* *}\right)$ and $\left(\mathrm{r}=0.765^{* *}\right.$ and $0.833^{* *}$ ) respectively (Table 7 ). Also, Aurduny genotype when harvested at first harvest in the first season and G2018 genotype when harvested after 20 days of PM in the second season were obtained the highest values of oil yield (1261.7 and $2398.4 \mathrm{~kg} \mathrm{ha}^{-1}$ ) respectively (Tables 5 and 6).

It is concluded that Rabee 500 genotype's plants gave the highest seed yield in both seasons; also, the plants harvested at physiological maturity gave the highest seed and oil yield in both seasons, while the highest value of oil yield was recorded by Al-mais genotype in the first season and G2018 genotype in the second season.

Table 3. Yield components, yield and oil quality of safflower genotypes for both seasons (2010-2011) and (2011-2012).

\begin{tabular}{|c|c|c|c|c|c|c|c|c|c|c|}
\hline $\begin{array}{l}\text { Growing } \\
\text { season }\end{array}$ & Genotypes & $\begin{array}{l}\text { Plant } \\
\text { Height } \\
(\mathrm{cm})\end{array}$ & $\begin{array}{l}\text { No. of primary } \\
\text { branches } \\
\text { /plant }\end{array}$ & $\begin{array}{l}\text { No. of } \\
\text { Heads } \\
\text { /plant }\end{array}$ & $\begin{array}{l}\text { No. of } \\
\text { Seeds } \\
\text { /head }\end{array}$ & $\begin{array}{l}\text { I00-seed } \\
\text { weight (g) }\end{array}$ & $\begin{array}{l}\text { Seed Yield } \\
\left(\mathrm{kg} \mathrm{ha}^{-1}\right)\end{array}$ & H.I (\%) & $\begin{array}{l}\text { Oil } \\
\text { Content } \\
(\%)\end{array}$ & $\begin{array}{l}\text { Oil Yield } \\
\left(\mathrm{kg} \mathrm{ha}^{-1}\right)\end{array}$ \\
\hline \multirow{3}{*}{2010} & G2018 & $148.7 \mathrm{a}$ & $17.6 \mathrm{a}$ & $51.5 \mathrm{c}$ & $25.8 \mathrm{bc}$ & $4.40 \mathrm{~b}$ & $2243.3 c$ & $19.2 d$ & $30.9 c$ & $701.5 c$ \\
\hline & Gila & $149.1 \mathrm{a}$ & $14.7 \mathrm{~b}$ & $48.7 d$ & $32.4 \mathrm{a}$ & $4.76 b$ & $2235.0 \mathrm{c}$ & $21.4 \mathrm{c}$ & $26.9 \mathrm{e}$ & $618.4 d$ \\
\hline & Al-mais & $149.1 \mathrm{a}$ & $17.4 \mathrm{a}$ & $56.3 \mathrm{~b}$ & $29.3 \mathrm{ab}$ & $4.45 b$ & $2180.4 d$ & $33.9 \mathrm{a}$ & $28.4 d$ & $842.1 \mathrm{a}$ \\
\hline \multirow[t]{2}{*}{2011} & Aurduny & $147.1 \mathrm{a}$ & $17.5 \mathrm{a}$ & $52.4 \mathrm{c}$ & $23.4 \mathrm{bc}$ & $4.17 \mathrm{~b}$ & $2494.0 \mathrm{~b}$ & $25.5 b$ & $31.6 \mathrm{~b}$ & $803.4 \mathrm{~b}$ \\
\hline & Rabee 500 & $140.4 b$ & $18.3 \mathrm{a}$ & $62.5 \mathrm{a}$ & $19.8 \mathrm{c}$ & $5.04 \mathrm{a}$ & 2918.9a & $18.2 \mathrm{~d}$ & $32.5 \mathrm{a}$ & $712.0 \mathrm{c}$ \\
\hline \multirow{4}{*}{$\begin{array}{l}2011 \\
2012\end{array}$} & Gila & $116.9 \mathrm{a}$ & $15.7 \mathrm{~b}$ & $63.2 \mathrm{a}$ & $19.8 b$ & $3.70 \mathrm{~b}$ & $1411.7 d$ & $23.7 \mathrm{ab}$ & $27.7 d$ & $607.2 \mathrm{~b}$ \\
\hline & Al-mais & $103.6 \mathrm{~d}$ & $12.9 \mathrm{c}$ & $36.0 \mathrm{~d}$ & $20.2 b$ & $3.27 \mathrm{~b}$ & $1356.1 \mathrm{e}$ & $20.9 b$ & $30.5 \mathrm{c}$ & $418.9 c$ \\
\hline & Aurduny & $110.8 b$ & $19.5 \mathrm{a}$ & $57.2 \mathrm{~b}$ & $23.7 b$ & $3.50 \mathrm{~b}$ & $2084.7 b$ & $21.1 \mathrm{~b}$ & $32.7 b$ & $717.7 \mathrm{~b}$ \\
\hline & Rabee 500 & $99.7 \mathrm{e}$ & $20.3 a$ & $61.3 \mathrm{a}$ & $15.1 \mathrm{c}$ & $4.18 \mathrm{a}$ & $2137.6 a$ & $24.5 \mathrm{a}$ & $33.8 \mathrm{a}$ & $480.2 c$ \\
\hline
\end{tabular}

Table 4. The effect of harvesting date on yield components, yield and oil quality of safflower genotypes for both seasons (2010-2011) and (2011-2012) and their means.

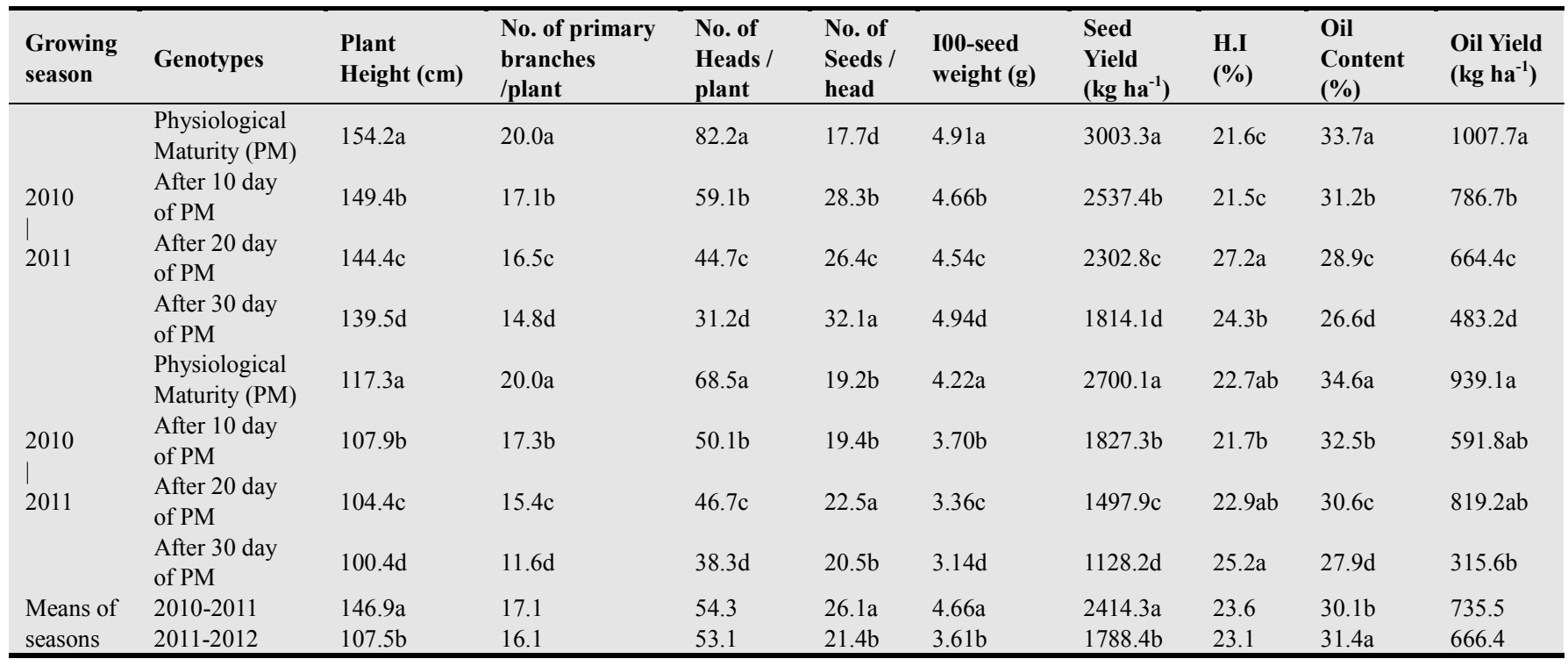

Values designed a different letters within a column indicates statistically significant differences according to Duncan's test. 
Table 5. The dual interaction effect on yield components, yield and oil quality of safflower genotypes of 2010-2011 seasons.

\begin{tabular}{|c|c|c|c|c|c|c|c|c|c|c|}
\hline Genotypes & $\begin{array}{l}\text { Harvesting } \\
\text { date }\end{array}$ & $\begin{array}{l}\text { Plant } \\
\text { Height } \\
\text { (cm) }\end{array}$ & $\begin{array}{l}\text { No. of primary } \\
\text { branches } \\
\text { /plant }\end{array}$ & $\begin{array}{l}\text { No. of } \\
\text { Heads/ } \\
\text { plant }\end{array}$ & $\begin{array}{l}\text { No. of } \\
\text { Seeds } \\
\text { /head }\end{array}$ & $\begin{array}{l}\text { I00-seed } \\
\text { weight } \\
\text { (g) }\end{array}$ & $\begin{array}{l}\text { Seed } \\
\text { Yield } \\
\left(\mathrm{kg} \mathrm{ha}^{-1}\right)\end{array}$ & $\begin{array}{l}\text { H.I } \\
(\%)\end{array}$ & $\begin{array}{l}\text { Oil } \\
\text { Content } \\
(\%)\end{array}$ & $\begin{array}{l}\text { Seed } \\
\text { Yield } \\
\left(\mathrm{kg} \mathrm{ha}^{-1}\right)\end{array}$ \\
\hline \multirow{4}{*}{ G2018 } & $\begin{array}{l}\text { Physiological } \\
\text { Maturity (PM) }\end{array}$ & $154.0 \mathrm{c}$ & $20.2 b$ & $75.0 \mathrm{c}$ & $16.3 \mathrm{e}$ & 4.48fgh & $2425.9 \mathrm{f}$ & $17.7 \mathrm{fg}$ & $35.4 \mathrm{a}$ & $859.1 \mathrm{e}$ \\
\hline & $\begin{array}{l}\text { After } 10 \text { day } \\
\text { of PM }\end{array}$ & $151.1 \mathrm{cde}$ & $17.7 \mathrm{ef}$ & $55.7 \mathrm{f}$ & $25.9 \mathrm{bc}$ & 4.43ghi & $2311.7 \mathrm{gh}$ & $18.9 \mathrm{ef}$ & $33.4 \mathrm{bc}$ & $771.6 \mathrm{f}$ \\
\hline & $\begin{array}{l}\text { After } 20 \text { day } \\
\text { of PM }\end{array}$ & $147.4 \mathrm{fg}$ & $16.8 \mathrm{gh}$ & $46.1 \mathrm{gh}$ & $25.5 \mathrm{bc}$ & 4.40ghi & 2296.2hi & $20.4 \mathrm{e}$ & $30.6 \mathrm{cf}$ & 699.0gh \\
\hline & $\begin{array}{l}\text { After } 30 \text { day } \\
\text { of PM }\end{array}$ & $142.2 \mathrm{ij}$ & $15.6 \mathrm{jk}$ & $29.2 \mathrm{k}$ & $35.1 \mathrm{a}$ & $4.27 \mathrm{ij}$ & 1949.21 & $19.6 \mathrm{ef}$ & $24.4 \mathrm{k}$ & $476.3 \mathrm{k}$ \\
\hline \multirow{4}{*}{ Gila } & $\begin{array}{l}\text { Physiological } \\
\text { Maturity (PM) }\end{array}$ & $163.7 \mathrm{a}$ & 16.7ghi & $81.9 \mathrm{~b}$ & $14.9 \mathrm{e}$ & $5.28 \mathrm{~b}$ & $2822.9 \mathrm{c}$ & $19.4 \mathrm{ef}$ & $32.4 \mathrm{~cd}$ & $914.9 \mathrm{~d}$ \\
\hline & $\begin{array}{l}\text { After } 10 \text { day } \\
\text { of PM }\end{array}$ & $152.2 \mathrm{~d}$ & $15.3 \mathrm{k}$ & $55.1 \mathrm{f}$ & $25.5 \mathrm{bc}$ & $5.01 \mathrm{c}$ & $2442.7 f$ & 19.9ef & $28.0 \mathrm{~h}$ & $684.0 \mathrm{~h}$ \\
\hline & $\begin{array}{l}\text { After } 20 \text { day } \\
\text { of PM }\end{array}$ & $140.7 \mathrm{ijk}$ & 14.11 & $43.6 \mathrm{~h}$ & $24.7 \mathrm{c}$ & $4.79 \mathrm{~d}$ & $2262.2 \mathrm{i}$ & $28.2 \mathrm{c}$ & $24.6 \mathrm{k}$ & $556.7 \mathrm{i}$ \\
\hline & $\begin{array}{l}\text { After } 30 \text { day } \\
\text { of PM }\end{array}$ & $139.6 \mathrm{jk}$ & $12.6 \mathrm{~m}$ & $29.0 \mathrm{k}$ & $28.5 \mathrm{~b}$ & $3.97 \mathrm{k}$ & $1414.1 \mathrm{~m}$ & $17.9 \mathrm{fg}$ & 22.51 & 317.91 \\
\hline \multirow{4}{*}{ Al-mais } & $\begin{array}{l}\text { Physiological } \\
\text { Maturity (PM) }\end{array}$ & $153.1 \mathrm{~cd}$ & $19.0 \mathrm{c}$ & $80.3 b$ & $21.6 \mathrm{~d}$ & 4.66de & $3569.8 \mathrm{a}$ & $27.1 \mathrm{~cd}$ & $31.0 \mathrm{e}$ & $1108.4 \mathrm{~b}$ \\
\hline & $\begin{array}{l}\text { After } 10 \text { day } \\
\text { of PM }\end{array}$ & $151.6 \mathrm{cde}$ & $17.8 \mathrm{ef}$ & $61.1 \mathrm{e}$ & $34.9 \mathrm{a}$ & 4.43ghi & $3370.1 b$ & $30.8 \mathrm{~b}$ & $29.8 \mathrm{fg}$ & $1005.5 \mathrm{c}$ \\
\hline & $\begin{array}{l}\text { After } 20 \text { day } \\
\text { of PM }\end{array}$ & $148.7 \mathrm{ef}$ & $17.4 \mathrm{fg}$ & $49.3 \mathrm{~g}$ & $26.6 \mathrm{bc}$ & $4.37 \mathrm{ghi}$ & $2528.0 \mathrm{e}$ & $39.3 \mathrm{a}$ & $26.9 \mathrm{i}$ & $681.8 \mathrm{~h}$ \\
\hline & $\begin{array}{l}\text { After } 30 \text { day } \\
\text { of PM }\end{array}$ & 143.0hi & $15.3 \mathrm{jk}$ & $34.3 \mathrm{ij}$ & $33.9 \mathrm{a}$ & $4.32 \mathrm{hi}$ & $2207.7 \mathrm{j}$ & $38.6 \mathrm{a}$ & $25.9 \mathrm{j}$ & $572.7 \mathrm{i}$ \\
\hline \multirow{4}{*}{ Aurduny } & $\begin{array}{l}\text { Physiological } \\
\text { Maturity (PM) }\end{array}$ & $157.9 \mathrm{~b}$ & $23.3 \mathrm{a}$ & $70.1 \mathrm{~d}$ & $25.4 \mathrm{bc}$ & $4.59 \mathrm{de}$ & $3477.5 \mathrm{a}$ & $27.5 \mathrm{~cd}$ & $35.3 \mathrm{a}$ & $1261.7 \mathrm{a}$ \\
\hline & $\begin{array}{l}\text { After } 10 \text { day } \\
\text { of PM }\end{array}$ & $150.5 \mathrm{de}$ & 16.1hij & $57.0 \mathrm{f}$ & $34.6 \mathrm{a}$ & $4.28 \mathrm{ij}$ & $2349.5 \mathrm{~g}$ & $19.7 \mathrm{ef}$ & $32.1 \mathrm{~d}$ & $754.3 \mathrm{f}$ \\
\hline & $\begin{array}{l}\text { After } 20 \text { day } \\
\text { of PM }\end{array}$ & $145.7 \mathrm{gh}$ & $16.0 \mathrm{ijk}$ & $36.1 \mathrm{i}$ & $34.7 \mathrm{a}$ & $4.15 \mathrm{j}$ & 2279.3hi & $29.2 \mathrm{bc}$ & $29.7 \mathrm{fg}$ & $677.9 \mathrm{~h}$ \\
\hline & $\begin{array}{l}\text { After } 30 \text { day } \\
\text { of PM }\end{array}$ & 134.21 & 14.41 & $31.5 \mathrm{jk}$ & $34.9 \mathrm{a}$ & 3.651 & $1769.8 \mathrm{~m}$ & $25.4 d$ & $29.4 \mathrm{~g}$ & $519.8 \mathrm{j}$ \\
\hline \multirow{4}{*}{ Rabee 500} & $\begin{array}{l}\text { Physiological } \\
\text { Maturity (PM) }\end{array}$ & 142.1ij & $20.5 b$ & $103.8 \mathrm{a}$ & $10.4 \mathrm{f}$ & $5.51 \mathrm{a}$ & $2618.9 d$ & $16.3 \mathrm{~g}$ & $34.1 \mathrm{~b}$ & $894.1 \mathrm{~d}$ \\
\hline & $\begin{array}{l}\text { After } 10 \text { day } \\
\text { of PM }\end{array}$ & 141.4ij & $18.5 \mathrm{~cd}$ & $66.4 d$ & $20.5 \mathrm{~d}$ & $5.17 \mathrm{~b}$ & $2213.0 \mathrm{j}$ & $18.2 \mathrm{efg}$ & $32.4 \mathrm{~cd}$ & $718.0 \mathrm{~g}$ \\
\hline & $\begin{array}{l}\text { After } 20 \text { day } \\
\text { of PM }\end{array}$ & $139.0 \mathrm{jk}$ & $18.2 \mathrm{de}$ & $48.2 \mathrm{~g}$ & $20.6 \mathrm{~d}$ & $4.97 \mathrm{c}$ & $2153.4 \mathrm{k}$ & $18.7 \mathrm{ef}$ & $32.7 \mathrm{~cd}$ & $706.7 \mathrm{gh}$ \\
\hline & $\begin{array}{l}\text { After } 30 \text { day } \\
\text { of PM }\end{array}$ & $138.3 \mathrm{k}$ & $15.9 \mathrm{jk}$ & $31.7 \mathrm{jk}$ & $27.7 \mathrm{bc}$ & $4.49 \mathrm{fg}$ & $1731.4 \mathrm{~m}$ & $19.7 \mathrm{ef}$ & $30.6 \mathrm{ef}$ & $529.3 \mathrm{j}$ \\
\hline
\end{tabular}

Values designed a different letters within a column indicates statistically significant differences according to Duncan's test.

Table 6. The dual interaction effect on yield components, yield and oil quality of safflower genotypes of 2011-2012 seasons.

\begin{tabular}{|c|c|c|c|c|c|c|c|c|c|c|}
\hline Genotypes & $\begin{array}{l}\text { Harvesting } \\
\text { date }\end{array}$ & $\begin{array}{l}\text { Plant } \\
\text { Height } \\
\text { (cm) }\end{array}$ & $\begin{array}{l}\text { No. of primary } \\
\text { branches } \\
\text { /plant } \\
\end{array}$ & $\begin{array}{l}\text { No. of } \\
\text { Heads/ } \\
\text { plant }\end{array}$ & $\begin{array}{l}\text { No. of } \\
\text { Seeds } \\
\text { /head } \\
\end{array}$ & $\begin{array}{l}\text { I00-seed } \\
\text { weight } \\
\text { (g) }\end{array}$ & $\begin{array}{l}\text { Seed } \\
\text { Yield } \\
\left(\mathrm{kg} \mathrm{ha}^{-1}\right)\end{array}$ & $\begin{array}{l}\text { H.I } \\
(\%)\end{array}$ & $\begin{array}{l}\begin{array}{l}\text { Oil } \\
\text { Content } \\
(\%)\end{array} \\
\end{array}$ & $\begin{array}{l}\text { Seed } \\
\text { Yield } \\
\left(\mathrm{kg} \mathrm{ha}^{-1}\right)\end{array}$ \\
\hline \multirow{4}{*}{ G2018 } & $\begin{array}{l}\text { Physiological } \\
\text { Maturity (PM) }\end{array}$ & $119.2 \mathrm{c}$ & $14.9 \mathrm{~g}$ & $59.2 \mathrm{e}$ & $31.5 \mathrm{a}$ & $4.14 \mathrm{~b}$ & $2969.9 \mathrm{c}$ & $23.3 \mathrm{ab}$ & $36.0 \mathrm{a}$ & $1069.1 \mathrm{~b}$ \\
\hline & $\begin{array}{l}\text { After } 10 \text { day } \\
\text { of PM }\end{array}$ & $106.3 \mathrm{gh}$ & $12.4 \mathrm{~h}$ & $56.1 \mathrm{e}$ & $22.1 \mathrm{cde}$ & $3.79 \mathrm{~cd}$ & $2052.9 \mathrm{e}$ & $26.8 \mathrm{a}$ & $34.5 \mathrm{bc}$ & $708.7 b c$ \\
\hline & $\begin{array}{l}\text { After } 20 \text { day } \\
\text { of PM }\end{array}$ & 103.0ijk & $10.5 \mathrm{i}$ & 39.5hi & $34.9 \mathrm{a}$ & $2.92 \mathrm{j}$ & $1776.1 \mathrm{~g}$ & $25.1 \mathrm{ab}$ & $33.5 \mathrm{~d}$ & $2399.4 a$ \\
\hline & $\begin{array}{l}\text { After } 30 \text { day } \\
\text { of PM }\end{array}$ & $97.8 \mathrm{~m}$ & 9.4ij & 37.0hi & $23.5 \mathrm{bcd}$ & $2.62 \mathrm{k}$ & 1007.91 & $26.1 \mathrm{a}$ & $25.4 \mathrm{j}$ & $256.3 \mathrm{~b}$ \\
\hline \multirow{4}{*}{ Gila } & $\begin{array}{l}\text { Physiological } \\
\text { Maturity (PM) }\end{array}$ & $127.3 \mathrm{a}$ & $20.1 \mathrm{bc}$ & $81.3 \mathrm{ab}$ & $24.4 b c$ & $4.13 b$ & $3297.5 b$ & $22.8 \mathrm{abc}$ & $33.2 \mathrm{~d}$ & $1093.5 \mathrm{~b}$ \\
\hline & $\begin{array}{l}\text { After } 10 \text { day } \\
\text { of PM }\end{array}$ & $119.3 \mathrm{c}$ & $18.8 \mathrm{~cd}$ & $65.2 \mathrm{~d}$ & $21.1 \mathrm{c}-\mathrm{f}$ & $3.67 \mathrm{cde}$ & $2233.0 \mathrm{~d}$ & $23.4 \mathrm{ab}$ & $29.0 \mathrm{~h}$ & $647.6 \mathrm{bc}$ \\
\hline & $\begin{array}{l}\text { After } 20 \text { day } \\
\text { of PM }\end{array}$ & $112.4 \mathrm{~d}$ & $15.4 \mathrm{fg}$ & $58.0 \mathrm{e}$ & 17.3efg & $3.56 \mathrm{def}$ & $1582.7 \mathrm{~h}$ & $24.6 \mathrm{ab}$ & $25.3 \mathrm{j}$ & $400.1 \mathrm{c}$ \\
\hline & $\begin{array}{l}\text { After } 30 \text { day } \\
\text { of PM }\end{array}$ & $108.5 \mathrm{ef}$ & $8.4 \mathrm{j}$ & $48.4 \mathrm{f}$ & $16.3 \mathrm{fg}$ & $3.44 \mathrm{e}-\mathrm{h}$ & $1225.6 \mathrm{k}$ & 27.1a & $23.4 \mathrm{k}$ & $328.2 \mathrm{c}$ \\
\hline
\end{tabular}




\begin{tabular}{|c|c|c|c|c|c|c|c|c|c|c|}
\hline Genotypes & $\begin{array}{l}\text { Harvesting } \\
\text { date }\end{array}$ & $\begin{array}{l}\text { Plant } \\
\text { Height } \\
\text { (cm) }\end{array}$ & $\begin{array}{l}\text { No. of primary } \\
\text { branches } \\
\text { /plant }\end{array}$ & $\begin{array}{l}\text { No. of } \\
\text { Heads/ } \\
\text { plant }\end{array}$ & $\begin{array}{l}\text { No. of } \\
\text { Seeds } \\
\text { /head }\end{array}$ & $\begin{array}{l}\text { I00-seed } \\
\text { weight } \\
\text { (g) }\end{array}$ & $\begin{array}{l}\text { Seed } \\
\text { Yield } \\
\left(\mathrm{kg} \mathrm{ha}^{-1}\right)\end{array}$ & $\begin{array}{l}\text { H.I } \\
(\%)\end{array}$ & $\begin{array}{l}\begin{array}{l}\text { Oil } \\
\text { Content } \\
(\%)\end{array} \\
\end{array}$ & $\begin{array}{l}\text { Seed } \\
\text { Yield } \\
\left(\mathrm{kg} \mathrm{ha}^{-1}\right)\end{array}$ \\
\hline \multirow{4}{*}{ Al-mais } & $\begin{array}{l}\text { Physiological } \\
\text { Maturity (PM) }\end{array}$ & $110.7 \mathrm{~d}$ & $24.3 \mathrm{a}$ & $82.6 \mathrm{a}$ & $12.9 \mathrm{~g}$ & $3.71 \mathrm{cde}$ & $1721.9 \mathrm{~g}$ & $24.8 \mathrm{ab}$ & $32.4 \mathrm{ef}$ & $558.2 \mathrm{bc}$ \\
\hline & $\begin{array}{l}\text { After } 10 \text { day } \\
\text { of PM }\end{array}$ & 103.6ij & $20.7 \mathrm{~b}$ & $71.5 \mathrm{c}$ & $13.8 \mathrm{~g}$ & $3.31 \mathrm{f}-\mathrm{i}$ & 1533.6hi & $15.1 \mathrm{c}$ & $31.9 \mathrm{f}$ & $488.7 \mathrm{c}$ \\
\hline & $\begin{array}{l}\text { After } 20 \text { day } \\
\text { of PM }\end{array}$ & $12.1 \mathrm{jkl}$ & $18.6 \mathrm{~d}$ & $54.7 \mathrm{e}$ & $16.5 \mathrm{fg}$ & $3.16 \mathrm{hij}$ & $1261.3 \mathrm{k}$ & $21.4 a b c$ & $29.7 \mathrm{~h}$ & $374.6 \mathrm{c}$ \\
\hline & $\begin{array}{l}\text { After } 30 \text { day } \\
\text { of PM }\end{array}$ & $97.9 \mathrm{~m}$ & $14.4 \mathrm{~g}$ & $36.3 \mathrm{hi}$ & 17.2efg & $2.90 \mathrm{jk}$ & $907.4 \mathrm{~m}$ & $22.3 \mathrm{ab}$ & $28.0 \mathrm{i}$ & $254.2 \mathrm{~d}$ \\
\hline \multirow{4}{*}{ Aurduny } & $\begin{array}{l}\text { Physiological } \\
\text { Maturity (PM) }\end{array}$ & $124.0 \mathrm{~b}$ & $23.2 \mathrm{a}$ & $77.3 b$ & $26.9 \mathrm{~b}$ & $4.17 \mathrm{~b}$ & 3603.3 & $20.6 a b c$ & $36.2 \mathrm{a}$ & 1303.3ab \\
\hline & $\begin{array}{l}\text { After } 10 \text { day } \\
\text { of PM }\end{array}$ & 110.4 ed & $21.3 b$ & $64.8 \mathrm{~d}$ & $18.7 \mathrm{def}$ & $3.54 \mathrm{~d}-\mathrm{g}$ & 1884.0f & $20.6 \mathrm{abc}$ & $33.0 \mathrm{de}$ & $621.9 \mathrm{bc}$ \\
\hline & $\begin{array}{l}\text { After } 20 \text { day } \\
\text { of PM }\end{array}$ & $107.7 \mathrm{fg}$ & $20.2 b$ & $46.0 \mathrm{fg}$ & $24.7 \mathrm{bc}$ & $3.24 \mathrm{ghi}$ & $1587.7 \mathrm{~h}$ & $19.1 \mathrm{bc}$ & $31.1 \mathrm{~g}$ & $493.9 b c$ \\
\hline & $\begin{array}{l}\text { After } 30 \text { day } \\
\text { of PM }\end{array}$ & $101.1 \mathrm{kl}$ & $16.5 \mathrm{ef}$ & $40.5 \mathrm{hi}$ & $24.4 \mathrm{bc}$ & $3.07 \mathrm{ij}$ & $1475.8 \mathrm{ij}$ & $24.1 \mathrm{ab}$ & $30.6 \mathrm{~g}$ & $451.7 \mathrm{c}$ \\
\hline \multirow{4}{*}{ Rabee 500} & $\begin{array}{l}\text { Physiological } \\
\text { Maturity (PM) }\end{array}$ & 105.0hi & $17.2 \mathrm{e}$ & $41.8 \mathrm{gh}$ & 19.1def & $4.95 \mathrm{a}$ & $1907.8 \mathrm{f}$ & $22.1 \mathrm{ab}$ & $35.2 b$ & $671.4 b c$ \\
\hline & $\begin{array}{l}\text { After } 10 \text { day } \\
\text { of PM }\end{array}$ & 100.21 & $13.0 \mathrm{~h}$ & 37.7hi & $21.1 \mathrm{c}-\mathrm{f}$ & $4.18 b$ & $1432.7 \mathrm{j}$ & $22.4 \mathrm{ab}$ & $34.3 \mathrm{c}$ & $492.1 b c$ \\
\hline & $\begin{array}{l}\text { After } 20 \text { day } \\
\text { of PM }\end{array}$ & $97.0 \mathrm{~m}$ & $12.4 \mathrm{~h}$ & $35.4 \mathrm{i}$ & 19.2def & $3.94 b c$ & $1282.1 \mathrm{k}$ & 27.1a & $33.5 \mathrm{~d}$ & $429.2 \mathrm{c}$ \\
\hline & $\begin{array}{l}\text { After } 30 \text { day } \\
\text { of PM }\end{array}$ & $96.7 \mathrm{~m}$ & $9.0 \mathrm{j}$ & $29.1 \mathrm{j}$ & $21.1 \mathrm{c}-\mathrm{f}$ & $3.66 \mathrm{cde}$ & 1024.31 & $26.5 \mathrm{a}$ & $32.0 \mathrm{f}$ & $328.2 \mathrm{c}$ \\
\hline
\end{tabular}

Values designed a different letters within a column indicates statistically significant differences according to Duncan's test.

Table 7. Values of correlation coefficients among characteristics of safflower genotypes.

\begin{tabular}{|c|c|c|c|c|c|c|c|c|c|c|}
\hline $\begin{array}{l}\text { Growing } \\
\text { season }\end{array}$ & Characteristics & $\begin{array}{l}\text { Seed } \\
\text { yield }\end{array}$ & $\begin{array}{l}\text { Plant } \\
\text { height }\end{array}$ & $\begin{array}{l}\text { No. of primary } \\
\text { branches/plant }\end{array}$ & $\begin{array}{l}\text { No. of } \\
\text { heads/plant }\end{array}$ & $\begin{array}{l}\text { No. of } \\
\text { seeds/ } \\
\text { head }\end{array}$ & $\begin{array}{l}\text { 100-seed } \\
\text { weight }\end{array}$ & $\begin{array}{l}\text { Harvest } \\
\text { index }\end{array}$ & $\begin{array}{l}\text { Oil } \\
\text { content }\end{array}$ & $\begin{array}{l}\text { Oil } \\
\text { yield }\end{array}$ \\
\hline \multirow{8}{*}{$\begin{array}{l}2010 \\
\mid \\
2011\end{array}$} & Plant height & $0.705^{* *}$ & 1.000 & & & & & & & \\
\hline & $\begin{array}{l}\text { No. of primary } \\
\text { branches/plant }\end{array}$ & $0.674 * *$ & $0.429 * *$ & 1.000 & & & & & & \\
\hline & No. of heads/plant & $0.673 * *$ & $0.559 * *$ & $0.709^{* *}$ & 1.000 & & & & & \\
\hline & No. of seeds/head & -0.228 & -0.256 & $-0.442 * *$ & $-0.726^{* *}$ & 1.000 & & & & \\
\hline & 100 -seed weight & 0.253 & 0.198 & 0.203 & $0.491 * *$ & $-0.728 * *$ & 1.000 & & & \\
\hline & Harvest index & 0.294 & 0.032 & -0.063 & -0.245 & $0.417 * *$ & -0.229 & 1.000 & & \\
\hline & Oil content & $0.465^{* *}$ & $0.430^{* *}$ & $0.731^{* *}$ & $0.660 * *$ & $-0.476^{* *}$ & $0.315^{*}$ & $-0.340 *$ & 1.000 & \\
\hline & Oil yield & $0.941 * *$ & $0.710^{* *}$ & $0.799 * *$ & $0.763 * *$ & $-0.356^{* *}$ & $0.301 *$ & 0.080 & $0.727 * *$ & 1.000 \\
\hline \multirow{8}{*}{$\begin{array}{l}2011 \\
\mid \\
2012\end{array}$} & Plant height & $0.887 * *$ & 1.000 & & & & & & & \\
\hline & $\begin{array}{l}\text { No. of primary } \\
\text { branches/plant }\end{array}$ & $0.493 * *$ & $0.524 * *$ & 1.000 & & & & & & \\
\hline & No. of heads/plant & $0.681 * *$ & $0.792 * *$ & $0.751 * *$ & 1.000 & & & & & \\
\hline & No. of seeds/head & $0.422 * *$ & 0.209 & -0.192 & -0.170 & 1.000 & & & & \\
\hline & 100 -seed weight & $0.447 * *$ & $0.353 * *$ & 0.193 & 0.193 & -0.150 & 1.000 & & & \\
\hline & Harvest index & -0.152 & -0.200 & $-0.428 * *$ & $-0.312 *$ & 0.063 & 0.062 & 1.000 & & \\
\hline & Oil content & $0.560 * *$ & 0.228 & $0.322 *$ & 0.213 & $0.365^{* *}$ & $0.076^{* *}$ & -0.155 & 1.000 & \\
\hline & Oil yield & $0.765^{* *}$ & $0.533^{* *}$ & $0.643^{* *}$ & $0.627 * *$ & $0.401 * *$ & 0.093 & 0.095 & $0.833 * *$ & 1.000 \\
\hline
\end{tabular}

*,** Significant at $\mathrm{p} \geq 0.05$ and 0.01 respectively

[3] Deedar, S.; Dalip, S.; Krishan, K.; Iqbal, S.; Singh, D.; kumar, K. and Singh, I. 1994. Performance of rainfed safflower (Carthamus tinctorius L.) under different nitrogen levels and row spacings. Indian Journal of Ecology, 21(1):23-28

[1] A.O.A.C., 1980. Association Official of Analytical Chemists. Offical methods of analysis 13th ed. Washington, D.C. USA

[4] FAO, Food and Agricultural organization of United Nations. 2013. Production Yearbook, Roma, Italy

[2] Dahnke, W. C.; Fanning, C. and Cattanach, A. 1992. Fertilizing safflower-NDSU extension service publication No. SF-727

[5] Khan, M. A.; S. Von witzke-Ehbrecht, B. L. Maass and H. C. Becker. 2009. Relationship among different geographical groups agromorphology, fatty acid composition and RAPD marker diversity in safflower (Carthamus tinctorius). Genetic 
48Makkiyah Kadhum Alag et al:: Response of Yield, Yield Components and Oil Quality of some Safflower Genotypes to Harvesting Date

Resources and Crop Evolution, 56: 19-30

[6] Martin, J. H.; waldren, R. P. and Stamp, D. L. 2006. Principles of Field Crop Production. Fourth Edition. Upper Saddle River, New Jersey, Columbus. Pp. 954

[7] Mohankumar, S. and V. P. Chimmad. 2005. Characterization of safflower genotypes for morpho-physilogical, yield and its components. Karnataka Journal Agriculture Science, 18(2): $312-315$

[8] Mosavi Mogaddam, S. L.; M. Tajbakhsh and A. Eivazi.2013. Evaluatuin of harvesting dates on qualitative traits of spring safflower (Carthamus tinctorius L.) genotypes under Urmia condition, Iranian Journal of Field Crops Research, 11(3): 454-459

[9] Mundel, H. H.; R. E. Blackshaw; R. Byers; H. C. Huang; D. L.
Johnson; R. Keon; J. Kubik; R. I. Mckenzie; B. Otto; B. Roth and K. Stanford. 2004. Safflower production on the Canadian Praivies. Agricultural and Agri-Food Canada pp: 3-10

[10] Qadir, G.; A. Shahbaz, F.; U. Hassan and M. A. Cheema. 2000. Oil and fatty acid accumulation in sunflower as influenced by temperature variation. Pak. J. Bot., 38(4): 1137-1147

[11] SAS (2005), Statistical Analysis System. SAS institute Inc., NC, USA. Releuse 82

[12] Soleymani, A.; Emami, S., A., Shahrajabian, M. H. and Naranjani; L. 2011. Evaluation of suitable planting dates and autumn safflower cultivars under climatic conditions of Isfahan, Iran. Research on Crops. 12(1): 155-162

[13] Steel, R. G. D. and J. H. Torrie. 1960. Principles and Procedures of Statistics Mc. Hill, New York. 